on the Great Skellig, yet could not rely upon an uncorroborated report as proof of the vertical distance at which the sea can occasionally act upon the weather side of a lofty rock. Its agency in forming some isolated pinnacles has not been denied.

Lospon, February 5th, 1867.

Truly yours, A. B. Wrank.

\title{
FISH IN THE DEVONIAN (NOT OLD RED) ROCKS.
}

\section{To the Editor of the Geologicar Magazine.}

SrR,-As there is still much misapprehension afloat as to the value of the fossil evidence in the case of "Devonian versus Old Red," it is desirable to clear up any doubtfal points. I believe it is admitted pretty generally that the greater part (not all, of course, of the so-called Carboniferous shells, crinoids, \&c., in our Devonian lists are orroneous identifications, made upon very imperfect specimens. At least I can answer for this in the greater part of those which have come under my review (see the revised names in the lower gallery, Museum P. Geol. Jermyn-street, and their catalogue); and Mr. Davidson has shown us the same thing in his careful monograph of the Carboniferous Brachiopods. There are a few exceptions, and, of course, these multiply in the highest beds.

But what about the Fish? It has been shown by many authors that Old Red fish occur in Devonian strata, and Devonian shells in Old Red Sandstone; and in a memoir laid before the Geological Society (Quart. Jour. Geol. vol. xix, p. 474, et seq), some years back, I endeavoured to collate these scattered evidences, and add others from persenal survey, which would show that the Upper Devonian fossils were found in Upper Old Red rocks; Middle Old Red fish were found in Middle Devonian; and, to complete the evidence derived from fossils, a Cephalaspid, from the undoubted Lover Devonian of the Rhenish provinces shewed that Lover Old Red meant Lower Devonian. In the absence of any physical evidence that the strata are not contemporaneous, it seemed to me that these fossil data were sufficient for the affirmative side of the question.

But it is argued by some that Coccosteus, found in the Eifel and in Russia with the shells, is, with us, as much an Upper as a Middle old Red form. And, moreover, that while Holoptychius (an undoubted upper Old Red fossil), has been found in the N. Devon rocks in its proper place. Phyllolepis has occurred in the lowest portion of the S. Devon series, near Torquay. Does any one know exactly where the specimen is on which this decision is founded? It used to be said that at Polperro, in Cornwall, in the Lower Devonian beds, fish were common. Professor M'Coy determined these to be sponge remains. Has any competent authority seen the Phyllolepis, and is the locality certain?

J. W. SALTEB. 